Article

\title{
The Impact of Microstructure of Filtration Materials on Its Auto-Activation for Manganese Removal from Groundwater
}

\author{
Zbysław Dymaczewski ${ }^{1} * \mathbb{D}^{\mathbb{D}}$, Joanna Falkowska ${ }^{1}$, Angelika Frąckowiak ${ }^{1}$, \\ Joanna Jeż-Walkowiak ${ }^{1}$, Justyna Nawrot ${ }^{1}$, Lidia Dudek ${ }^{2}$ and Tomasz Topór ${ }^{2}$ \\ 1 Institute of Environmental Engineering and Building Installations, Poznan University of Technology, 60-965 \\ Poznań, Poland; joanna.falkowska@onet.pl (J.F.); angela.frackowiak@gmail.com (A.F.); \\ joanna.jez-walkowiak@put.poznan.pl (J.J.-W.); justynaa.nawrot@gmail.com (J.N.) \\ 2 Oil and Gas Institute-National Research Institute, 31-503 Kraków, Poland; dudekl@inig.pl (L.D.); \\ toport@inig.pl (T.T.) \\ * Correspondence: zbyslaw.dymaczewski@put.poznan.pl
}

Received: 18 April 2020; Accepted: 29 May 2020; Published: 30 May 2020

check for updates

\begin{abstract}
The study investigates the impact of pore structure parameters of three chemically non-active filtration materials on the auto-activation time and the height of the filtration zone for manganese removal from groundwater. At a technical scale, the activation is a long process which may require a period of up to three months. The process can be shortened by the use of porous filtration materials. In this study, three filtration materials (silica sand, chalcedonite sand, GAC-granulated activated carbon) were investigated using subcritical nitrogen adsorption and mercury injection capillary pressure measurements. These methods provide a comprehensive evaluation of pore structure parameters, including specific surface area (SSA), micro- and mesopore volumes, and an extended range of pore size distribution (PSD). The studied materials provided a wide range of micro- and mesopore volumes as well as SSA. In order to investigate the auto-activation time of filtration material - the time required to achieve the requested quality of the filtrate-and the height of the filtration zone, a pilot experiment was conducted for $1950 \mathrm{~h}$. The pilot installation consisted of three-meters-high (10 cm diameter) filtration columns filled with the tested filtration materials. The results indicate that the internal pore structure and the investigated auto-activation parameters are correlated. Both auto-activation time and the size of the filtration zone were influenced by the mesopore volume and the associated SSA of the tested materials. The micropore volume was less effective in improving the autoactivation parameters. The research results indicated the importance of pore structure characteristics which should be considered prior to time-consuming pilot and technological tests.
\end{abstract}

Keywords: groundwater; manganese removal; oxide coated media; internal pore structure; autocatalytic manganese oxidation; auto-activation parameters

\section{Introduction}

Removal of manganese from groundwater occurs during the aeration and filtration processes at the treatment plant. Treatment is based on the transformation of soluble Mn(II) compounds into Mn(IV) compounds, which are practically insoluble in water and may be easily removed using the filtration material. The oxidation of manganese is an autocatalytic process. During filtration, the product of manganese oxidation forms a permanent oxide coating on the grains of filtration material. The process of covering grains with catalytic layers is called auto-activation. The catalytic layer plays a primary 
role in manganese oxidation and its removal from the groundwater. The process of auto-activation is characterized by the following parameters [1,2]:

- the time needed to reach auto-activation,

- the height of the manganese removal zone in a filter bed.

This study presents research data regarding the process of auto-activation of chemically non-active filtration materials for the removal of manganese from groundwater. In traditional groundwater treatment systems based on aeration followed by rapid filtration with no chemical dosage, manganese removal is possible due to the presence of manganese dioxide catalyst on the grains of the filtration material [3-5]. The chemically non-active filtration material, such as silica sand, has to be activated first by covering the grains with manganese dioxide during the filtration of natural groundwater [6]. After activation of filtration material, manganese removal becomes an autocatalytic and heterogenic process [2,5].

The auto-activation of silica sand is a time-consuming process, and it may even take two months under technical conditions at the groundwater treatment plant [7]. However, auto-activated materials allow to achieve very high and very stable efficiency of manganese removal in comparison to artificially activated materials available on the market [3]. To reduce the time of auto-activation, porous filtration materials such as chalcedonite and granulated activated carbon were introduced. The internal pore structure allows to achieve auto-activation more rapidly, after approximately three weeks [8]. High values of the specific surface area (SSA) and pore volume create niches for microbial growth, thus initiating the process of auto-activation (ripening process) as well as promoting the coverage of the grains with $\mathrm{MnO}_{2}$ (permanent oxide coating, the product of manganese oxidation) [1,9-11].

The pore structure of media grains can be established using various techniques [12]. Among several possible approaches, adsorption methods are commonly used to characterize filtration materials $[13,14]$.

\section{Goal and Scope of the Research}

The goal of the presented research was to establish a relation between the internal pore structure parameters of three filtration materials and auto-activation parameters. The auto-activation parameters are represented by the time of auto-activation and the height of the manganese removal zone in filter depth.

The time of auto-activation is the time when the filter reaches stable efficiency of manganese removal, which results in an outlet manganese concentration lower than the limit value of $0.05 \mathrm{mg}$ $\mathrm{Mn} / \mathrm{L}$.

\section{Materials and Methods}

\subsection{General Description}

The research on the auto-activation process was conducted using three chemically non-active filtration materials.

A pilot plant experiment was carried out in order to establish the influence of microstructure of filtration materials (SSA and pore volumes) on auto-activation parameters.

The filtration experiment was conducted according to the methodology applied in corresponding research [15]. The experimental installation should consist of filtration columns high enough to achieve a 1:1 ratio with the technical scale depth of a filter bed [3]. Additionally, in order to avoid the wall effect, the diameter should be at least equal to $10 \mathrm{~cm}$. The duration of the filtration experiment should be long enough to reach the effluent quality which meets the standards [8]. A properly designed experiment should indicate which equilibrium conditions are appropriate for the long-term operation of filters [5,16-18]. During the experiment, 17 filtration cycles for each of the tested media were conducted. The total filtration time of tested media was $1950 \mathrm{~h}$. This long-term experiment allowed to establish the time needed for auto-activation of media for manganese removal from groundwater as well as to establish the equilibrium manganese removal zone in the investigated filtration beds. 
The manganese removal zone is a part of the filter bed depth in which the manganese removal occurs. When the concentration in the filter outlet reached $0.05 \mathrm{mg} \mathrm{Mn} / \mathrm{L}$, the manganese zone is the entire height of the filter bed. Further filtration and the subsequent activation process lead to a reduction of the manganese removal layer. After the final activation of the bed and achieving equilibrium of the manganese removal (i.e., after establishing an oxide coating-catalytic layer), its height reaches the minimum value, which is characteristic for a given material.

\subsection{Characterization of Filtration Material}

During the research, three non-chemically active materials were tested:

- $\quad$ silica sand;

- chalcedonite sand;

- granulated activated carbon (GAC) (not being used for manganese removal at a technical scale; in the described research it serves as a reference material with very high internal porosity).

Silica sand is a popular filtration material applied for groundwater and surface water filtration [6]. Mined chalcedonite is a sedimentary rock formed from dissolution, precipitation, and crystallization, derived from dead organisms living in warm and shallow seas. Similar to silica sand, chalcedonite is chemically homogenous and consists mostly of $\mathrm{SiO}_{2}$ but is characterized by internal porosity in contrast to silica sand [5,19]. Chalcedonite is a mineral which occurs in the form of solid rock formations interleaved with chalcedonite silt; hence, the technology for the preparation of chalcedonite filter sand includes, among others, mechanical crushing and grinding of this mineral, rinsing and hydraulic classification, drying and dry fractionation $[6,19]$. GAC was used as a comparative material with high internal porosity and SSA.

The granular parameters of tested filtration materials are listed in Table 1 . These parameters were determined based on the results of the sieve analysis.

Table 1. Granulometric parameters of tested filtration materials.

\begin{tabular}{cccc}
\hline \multirow{2}{*}{$\begin{array}{c}\text { Granulometric } \\
\text { Parameter }\end{array}$} & Silica Sand & Chalcedonite Sand & GAC \\
\cline { 2 - 4 } & & $\mathbf{( m m )}$ & \\
\hline $\mathrm{d}_{\min }$ & 0.50 & 0.50 & 0.50 \\
$\mathrm{~d}_{\max }$ & 2.00 & 2.00 & 2.00 \\
$\mathrm{~d}_{10}$ & 1.05 & 1.03 & 0.95 \\
$\mathrm{~d}_{60}$ & 1.50 & 1.50 & 1.63 \\
$\mathrm{~d}_{90}$ & 1.80 & 1.88 & 1.92 \\
\hline
\end{tabular}

GAC, granulated activated carbon.

The values of granulometry parameters are almost equal for all three tested materials. The granulometry of tested materials was selected to ensure similarity of the filtration bed structure.

\subsection{Pore Structure Parameters}

Pore structure characteristics were evaluated using samples crushed in a mortar which were passed through a sieve of 0.5-1.0 mm. Samples were split into two homogeneous aliquots for subcritical gas adsorption (SGA) and mercury injection capillary pressure (MICP) measurements. The measurements were performed using samples preheated at $105^{\circ} \mathrm{C}$ for $24 \mathrm{~h}$ [20].

\subsection{Subcritical Gas Adsorption}

Nitrogen subcritical gas adsorption (SGA) isotherms at $-195.8^{\circ} \mathrm{C}(77 \mathrm{~K})$ were obtained using a Tristar II 3020 apparatus (Micromeritisc). The SGA method covers a pore-size range from $1.7 \mathrm{~nm}$ to $\sim 200 \mathrm{~nm}$. The measurements were carried out after the additional step of heating to $105^{\circ} \mathrm{C}$ using a 
SmartPrep apparatus (as a part of Tristar 3020) operating in a pre-programmed $15 \mathrm{~h}$ cycle with a ramp of $10^{\circ} \mathrm{C} / \mathrm{min}$ and nitrogen as a drying gas. After drying, the samples were placed inside the measuring tube, flushed with helium, and evacuated. Full adsorption and desorption cycles were performed over the entire partial pressure range, with an average number of 52 measurement points. Specific surface area (SSA) was determined using a modified BET analysis procedure proposed by Rouquerol et al. [21]. Micropore volume was estimated using the t-plot technique and the Harkins-Jura thickness equation, which describes the statistical thickness of the adsorbate multilayer on the pore surface. PSD was calculated using the Barett-Joyner-Halenda $(\mathrm{BJH})$ method by inverting the adsorption branch of the isotherm and assuming cylindrical non-connecting pores. The statistical thickness from Harkins-Jura was used for the multilayer adsorbed volume in the BJH inversion [22].

\subsection{Mercury Injection Capillary Pressure (MICP)}

The MICP measurements were performed using an AutoPore IV 9500 Series Mercury Porosimeter (Micromeritisc) with pressure steps from 0 to $60,000 \mathrm{psi}$, covering the pore throat diameter range from approximately $300 \mu \mathrm{m}$ to $0.004 \mu \mathrm{m}(4 \mathrm{~nm})$. The conformance and compaction corrections were applied to all MICP curves, using the approach of Brown [23]. Conformance and compaction are artifacts and have been recognized as the source of error when computing petrophysical properties from MICP experimental results [24,25]. The obtained pressure data were converted to the pore throat size distribution (PSD) using the Washburn equation [26]. The data obtained from MICP measurements were used as complementary information about PSD of the studied materials.

\subsection{Water Supplying Filtration Columns}

The experimental installation was supplied with model water prepared using tap water with manganese compound addition. The quality of water subjected to filtration is presented in Table 2.

Table 2. Experimental water quality.

\begin{tabular}{ccc}
\hline Water Quality Parameters & Unit & Value \\
\hline manganese & $\mathrm{mg} \mathrm{Mn} / \mathrm{L}$ & $0.31-0.79$ \\
total iron & $\mathrm{mg} \mathrm{Fe} / \mathrm{L}$ & 0.045 \\
$\mathrm{pH}$ & - & $7.14-7.89$ \\
alkalinity & $\mathrm{mval} / \mathrm{L}$ & $3.75-3.9$ \\
acidity & $\mathrm{mval} / \mathrm{L}$ & $0.05-0.125$ \\
conductivity & $\mu \mathrm{SS} / \mathrm{cm}$ & $497-532$ \\
COD-Mn* & $\mathrm{mg} \mathrm{O} / / \mathrm{L}$ & $2.90-4.2$ \\
Total hardness & $\mathrm{mval} / \mathrm{L}$ & $5.75-8.57$ \\
chloride & $\mathrm{mg} \mathrm{Cl} / \mathrm{L}$ & $56-62$ \\
turbidity & $\mathrm{NTU}$ & $0.17-0.74$ \\
color & $\mathrm{mg} \mathrm{Pt} / \mathrm{L}$ & $10-15$ \\
ammonium & $\mathrm{mg} / \mathrm{L}$ & $0.018-0.021$ \\
nitrate & $\mathrm{mg} \mathrm{NO} / \mathrm{L}$ & 0.085 \\
nitrite & $\mathrm{mg} \mathrm{NO}_{2} / \mathrm{L}$ & 0.0095 \\
\hline
\end{tabular}

${ }^{*}$ Chemical Oxygen Demand measured with potassium permanganate.

\subsection{Filtration Experiment}

The pilot plant consisted of three filtration columns with a height of $3 \mathrm{~m}$ and diameters of $10 \mathrm{~cm}$. The experimental installation was supplied with aerated model water with a manganese concentration of $0.31-0.79 \mathrm{mg} \mathrm{Mn} / \mathrm{L}$. The filtration rate was constant during the tests and reached $6 \mathrm{~m} / \mathrm{h}$. The depth of the filtration bed was equal to $1.6 \mathrm{~m}$. There was a support layer of $20 \mathrm{~cm}$ of gravel below the bed.

Each filter was equipped with ten piezometers, spaced every $20 \mathrm{~cm}$, and the same number of sampling valves. Analysis of water collected from various depths enabled the formation of a 
concentration profile at a depth of the filtration bed. Analysis of manganese in the inflow, outflow, and depth of the bed was performed once a day.

The filtration cycles ranged from 80 to $122 \mathrm{~h}$. During the research, 17 filtration cycles were conducted; the columns were backwashed with water after each filtration cycle.

\section{Results and Discussion}

\subsection{Pore Structure Characteristics}

The isotherms of studied samples show a remarkable difference in terms of shape, which gives a qualitative indication of the porous structure of the materials (Figure 1).

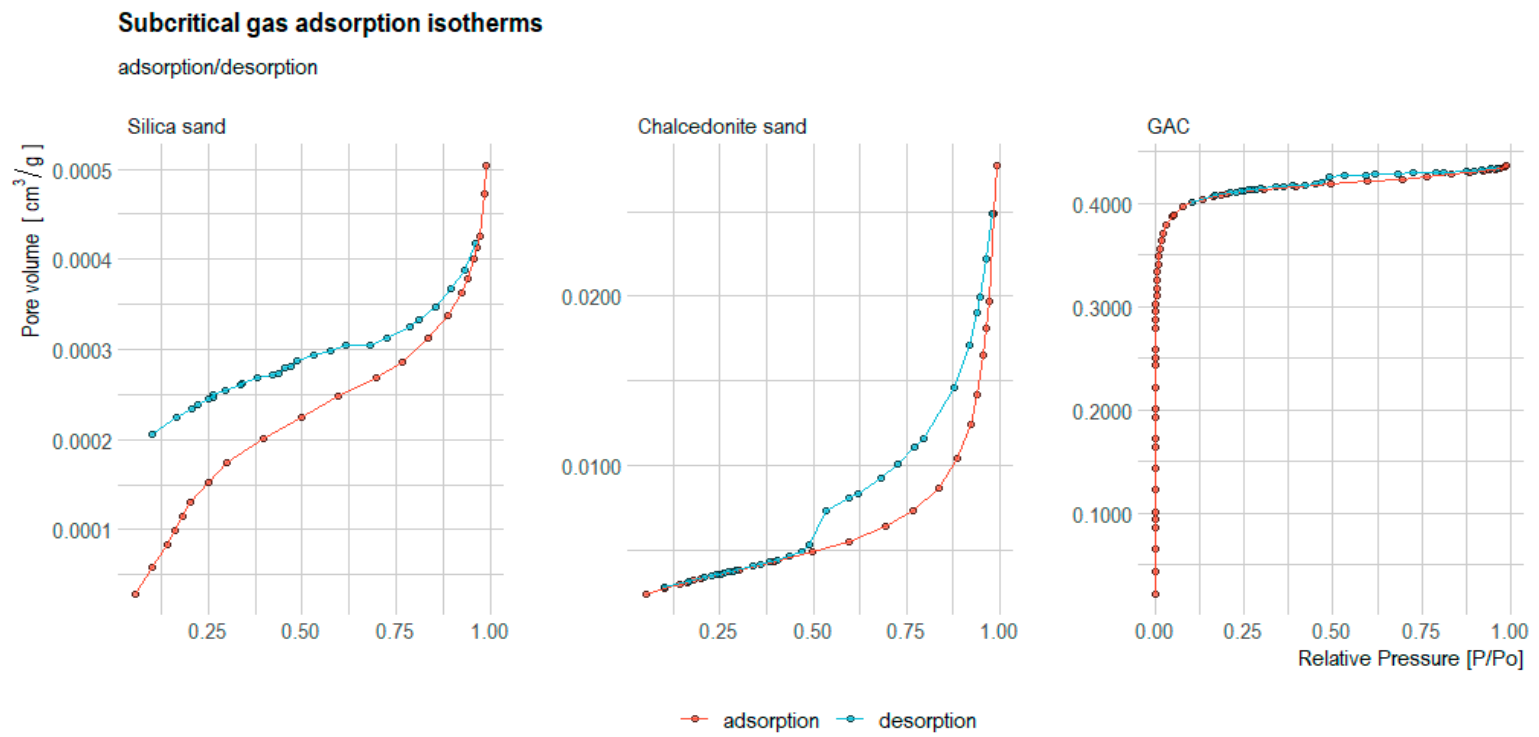

Figure 1. Subcritical gas adsorption (SGA) isotherms with adsorption (red) and desorption (blue) branches for studied samples (note differences in y-scale).

The amount of nitrogen adsorbed by silica sand is negligibly low due to the absence of porosity $\left(0.0005 \mathrm{~cm}^{3} / \mathrm{g}\right.$ - within the range of experimental uncertainty). Thus, the theoretical consideration of pore structure is difficult for this sample. The shape of the adsorption curve, however, indicates Type II isotherm, which is characteristic for non-porous materials (The International Union of Pure and Applied Chemistry-IUPAC).

The chalcedonite sand exhibits a significant hysteresis pattern and no plateau at high $\mathrm{P} / \mathrm{Po}$ (Figure 1). According to Rouquerol et al. [27], this type of nitrogen isotherm is characteristic for Type IIB. The isotherm indicates that the material possesses both mesopores and macropores which are responsible for the presence of hysteresis and the absence of a plateau at high $\mathrm{P} / \mathrm{Po}$. The isotherm pattern shows the so-called force-closure of the desorption branch at $\mathrm{P} / \mathrm{Po}$ at 0.55 to $0.35 \mathrm{P} / \mathrm{Po}$ which is caused by the tensile strength effect [22]. Such an isotherm profile indicates a significant contribution of fine mesopores [28]. Indeed, the studied sample possessed approx. $12 \%$ of pores with a diameter of $2-5$ $\mathrm{nm}$ (Table 3). The steep slope of the adsorption branch at P/Po 0.98-1.0 and the associated significant volume uptake indicate large pore volumes in the $\sim 200 \mathrm{~nm}$ pore-size range. The total amount adsorbed by chalcedonite sand is equal to $0.0277 \mathrm{~cm}^{3} / \mathrm{g}$. For mesopores $(2-50 \mathrm{~nm})$, this amount is equal to 0.0188 $\mathrm{cm}^{3} / \mathrm{g}$ (Table 3).

The GAC exhibited a concave shape isotherm with very high adsorption at low $\mathrm{P} / \mathrm{Po}$, typical for Type I isotherm of microporous materials. In medium and high $\mathrm{P} / \mathrm{Po}$ ranges, the slope of the isotherm is small, which indicates a poorly developed mesoporous system (Figure 1). The hysteresis loop is negligible. The amount adsorbed for GAC is the highest among the studied samples and equal to 
$0.4359 \mathrm{~cm}^{3} / \mathrm{g}$. Mesopores constitute approx. $5 \%$ of the total pore volume $\left(0.02604 \mathrm{~cm}^{3} / \mathrm{g}\right)$, and the majority is associated with pores with a diameter of $2-5 \mathrm{~nm}$ (Table 3 ).

Table 3. Pore structure parameters from SGA for studied samples.

\begin{tabular}{cccccc}
\hline Sample & $\begin{array}{c}\text { Total Pore } \\
\text { Volume } \\
\left(\mathbf{c m}^{3} / \mathbf{g}\right)\end{array}$ & $\begin{array}{c}\text { Mesopore } \\
\text { Volume 2-50 } \\
\mathbf{n m ~}\left(\mathbf{c m}^{3} / \mathbf{g}\right)\end{array}$ & $\begin{array}{c}\text { Fine Mesopore } \\
\text { volume }<2-5 \\
\mathbf{n m ~}\left(\mathbf{c m}^{3} / \mathbf{g}\right)\end{array}$ & $\begin{array}{c}\text { t-Plot } \\
\text { Micropore } \\
\text { Volume }<2 \\
\mathbf{n m}\left(\mathbf{c m}^{3} / \mathbf{g}\right)\end{array}$ & SSA $\left(\mathbf{m}^{2} / \mathbf{g}\right)$ \\
\hline $\begin{array}{c}\text { Silica sand } \\
\text { Chalcedonite } \\
\text { sand }\end{array}$ & 0.0005 & 0.00024 & 0.00013 & 0 & 0.54 \\
GAC & 0.0277 & 0.01875 & 0.00342 & 0 & 7.69 \\
\hline
\end{tabular}

SGA, subcritical gas adsorption; SSA, specific surface area.

For both silica sand and chalcedonite sand, the t-plot micropore volume is negligible and within the range of experimental uncertainty. The GAC is characterized by a very high t-plot micropore volume $\left(0.4058 \mathrm{~cm}^{3} / \mathrm{g}\right)$, which consists of $93 \%$ of the detected pore volume. The nonporous silica sand is characterized by the lowest SSA of $0.54 \mathrm{~m}^{2} / \mathrm{g}$. The SSA for chalcedonite sand is equal to $7.69 \mathrm{~m}^{2} / \mathrm{g}$, and it is associated with the mesopore structure. Due to the high nanopore content, GAC possesses the highest SSA equal to $1051.20 \mathrm{~m}^{2} / \mathrm{g}$ (Table 3). It should be highlighted, however, that this SSA is underestimated due to the resolution limit of N2 SGA analysis which does not include pores smaller than $1.7 \mathrm{~nm}$.

PSD from SGA and MICP provides complementary information regarding the pore structure in the studied samples. The PSD $d V / d \log D\left(\mathrm{~cm}^{3} / \mathrm{g}\right)$ parameter was used to present pore volume because the area under the curve can be used to calculate partial pore volume [22]. Although the pore-size range overlaps for both methods (from $\sim 4$ to $\sim 200 \mathrm{~nm}$ ), the PSD curves do not match perfectly (Figure 2). This discrepancy results from the fact that the adsorption process allows to establish pore-body distribution, and the $\mathrm{Hg}$ intrusion provides pore-throat size [28,29]. Due to the low adsorption and intrusion volumes, the PSD for silica sand cannot be interpreted. The SGA PSD for chalcedonite sand exhibits bimodal distribution with a major peak at approx. $60-80 \mathrm{~nm}$ and a minor peak at approx. $2-5 \mathrm{~nm}$ (Figure 2). The major peak from MICP PSD is located at approx. $5 \mu \mathrm{m}$ (interparticle pores) for chalcedonite sand. The SGA PSD for highly microporous GAC shows a steep slope in the nanopore range, which is followed by a minor peak at approx. $10 \mathrm{~nm}$ (Figure 2). The same trend, although shifted towards higher pore volumes for the entire pore size range, can be observed from MICP PSD. This discrepancy can result in pore structure changes, such as possible particle breakdown [30]. GAC also exhibits a major peak at approx. 2-4 $\mu \mathrm{m}$. The analysis of SGA allowed to provide the best description of the pore structure of the studied materials.

\subsection{Auto-Activation Research}

During the research, the process of auto-activation of tested media for catalytic removal of manganese was conducted. The auto-activation process occurs gradually during the filtration of water with manganese content. During the filtration, the grains are covered with manganese IV oxides. Gradually, a stable catalytic layer is formed on each bed grain. Only the autoactivated, oxide-coated bed can adsorb and catalytically oxidize manganese II dissolved in water to form precipitated Mn (IV) oxides [1,17].

Three graphs which represent the process of auto-activation of the tested materials in the form of the dependence of manganese concentration in the effluent from the filtration column on the time when the bed was operated are presented in Figure 3. The charts also indicate the concentration of manganese in the filter inflow and the limit value for manganese in drinking water $(0.05 \mathrm{mg} \mathrm{Mn} / \mathrm{L} —$ dashed line $)$. 


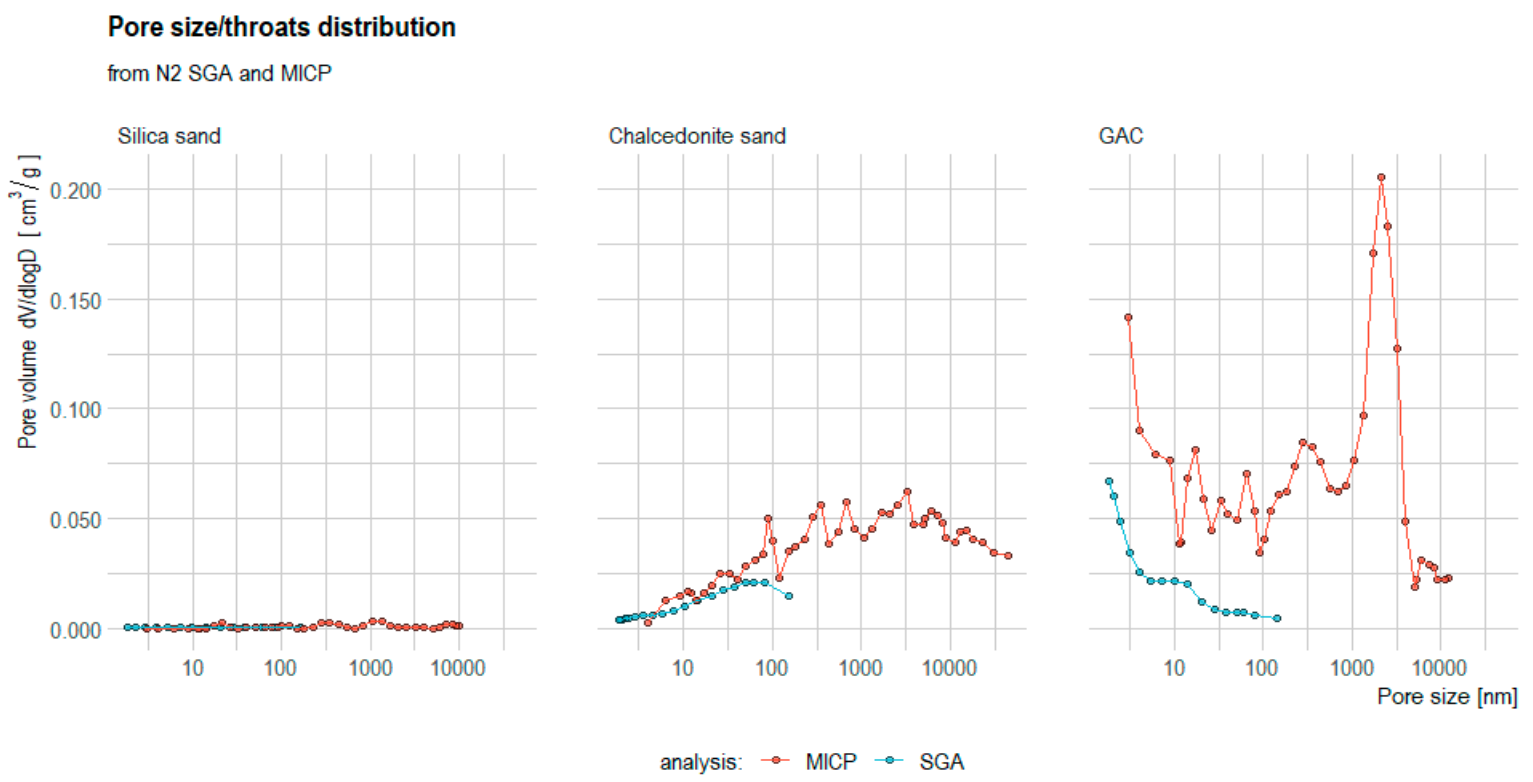

Figure 2. Combined pore size distribution (PSD) from SGA (blue) and mercury injection capillary pressure (MICP) (red). The same scale was used to present the results.

\section{Autoactivation curves for tested filtration materials}

dashed line represents a threshold level of $0.05 \mathrm{mg} / \mathrm{L}$

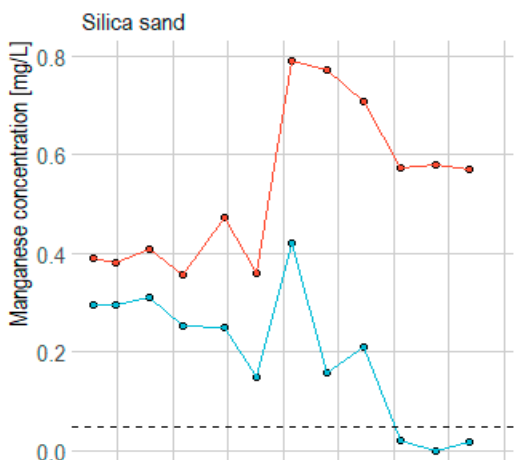

$200 \quad 400 \quad 600 \quad 800 \quad 1000120014001600$

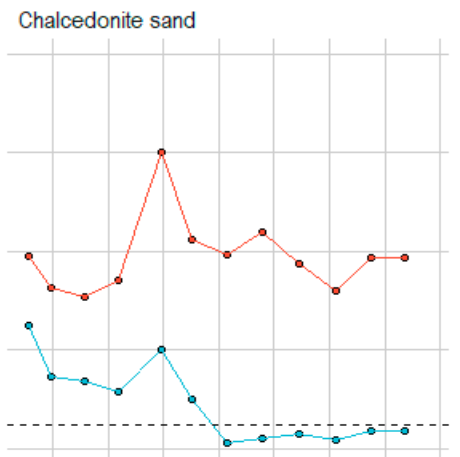

$200 \quad 400 \quad 600 \quad 800 \quad 1000120014001600$

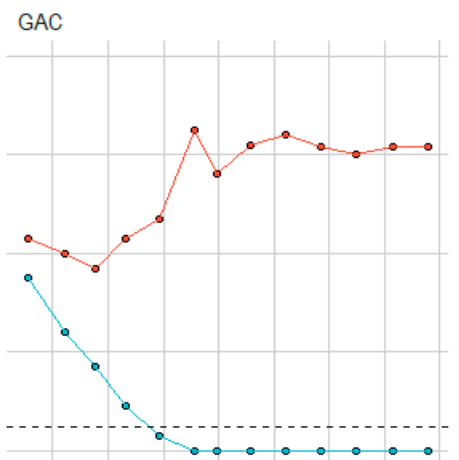

$200 \quad 400 \quad 600 \quad 800 \quad 1000120014001600$

Filtration time $[\mathrm{h}]$

$\circ$ inlet $\circ$ outlet

Figure 3. Auto-activation curves for tested filtration materials.

The auto-activation time of the deposit determines the moment of receiving a lower value of 0.05 $\mathrm{mg} \mathrm{Mn} / \mathrm{L}$ in the outflow. The time of auto-activation for the respective tested filtration materials was equal to

- $570 \mathrm{~h}$ (approximately 24 days) in the case of GAC,

- $770 \mathrm{~h}$ (32 days) in the case of chalcedonite,

- $1200 \mathrm{~h}$ (50 days) in the case of silica sand.

During the experiment, relatively short auto-activation times were achieved mainly in the case of GAC and chalcedonite sand, although the manganese concentration in raw water was low. The auto-activation process at a technical scale is time-consuming and can last for 2-3 months [8]. If the manganese concentration is low in the raw water (at the level of $0.2-0.3 \mathrm{mg} \mathrm{Mn} / \mathrm{L}$ ), the auto-activation process may be even longer or may not occur. Auto-activation time can be reduced by using porous beds. The pores in the grains of the deposits provide areas where active centers are formed more easily, 
which then grow into a catalytic layer [1]. Additionally, pores create a niche wherein manganese bacteria may oxidize manganese in the biochemical process. The biochemical oxidation initiates auto-activation in the initial phase of this process $[2,11]$. Because of the internal porosity, the auto-activation in GAC requires the lowest amount of time. Furthermore, the activation of chalcedonite was considerably shorter than silica sand. The differences in terms of auto-activation time of investigated materials are influenced by differences in terms of the internal pore structure parameters. The silica sand is a bed with virtually no internal porosity. The estimated total pore volume of silica sand was equal to $0.0005 \mathrm{~cm}^{3} / \mathrm{g}$, and SSA is equal to $0.54 \mathrm{~m}^{2} / \mathrm{g}$. The estimated total pore volume of chalcedonite was equal to $0.0277 \mathrm{~cm}^{3} / \mathrm{g}$, this value is 55 times greater than that estimated for silica sand, whereas SSA of chalcedonite is equal to $7.69 \mathrm{~m}^{2} / \mathrm{g}$ and is 14 times greater than that of silica sand. As it was assumed, a well-developed structure of mesopores of chalcedonite grains significantly affected its adsorption capacity as well as the colonization of microorganisms as in case of GAC [31]. Despite the fact that GAC is characterized by a high adsorption capacity in relation to organics and inorganics, it requires time to start the removal of manganese from treated water. During our research, GAC was activated after 24 days of filtration, which was surprising for the authors since a much shorter start-up was expected.

The time of auto-activation corresponds to the height of the manganese zone, which is equal to the height of the filter bed. During the further operation of the filter, the height of the manganese zone is gradually reduced, allowing for the removal of manganese from the treated water in the upper layer of the bed to achieve a stable minimum value at some point. Each of the tested materials reached a different minimum value for this parameter.

Figure 4 presents the variation in the height of the manganese removal zone from the time the bed is operated after auto-activation to determine the minimum value of the removal zone.

Variation in height of the manganese removal zone

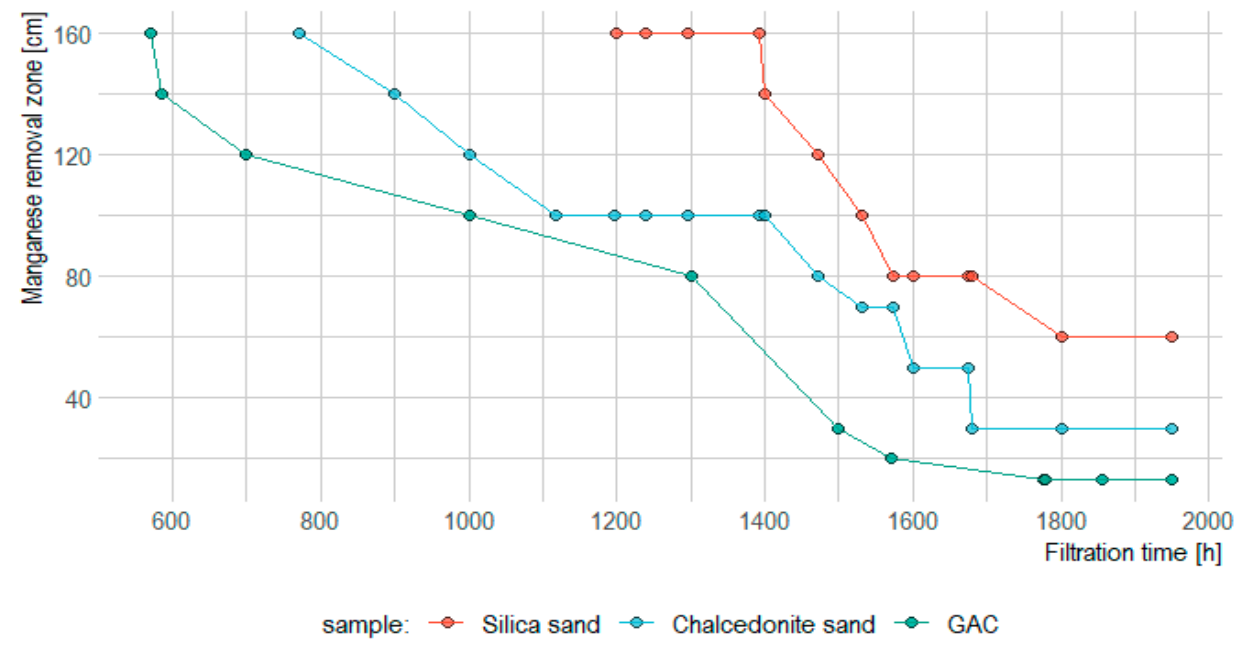

Figure 4. Variation in the height of the manganese removal zone of the tested filter media.

The differences in manganese removal zones and auto-activation times of tested media correspond with the differences in terms of internal pore structure parameters. Graphs in Figure 5 represent the dependence of auto-activation parameters of the tested materials on:

- $\quad$ total pore volume $(\sim 2-150 \mathrm{~nm})$

- mesopore volume ( 2-50 nm)

- fine mesopore volume $(\sim 2-5 \mathrm{~nm})$

- SSA 
Impact of pore structure parameters on height of $\mathrm{Mn}$ removal zone and autoactivation timee
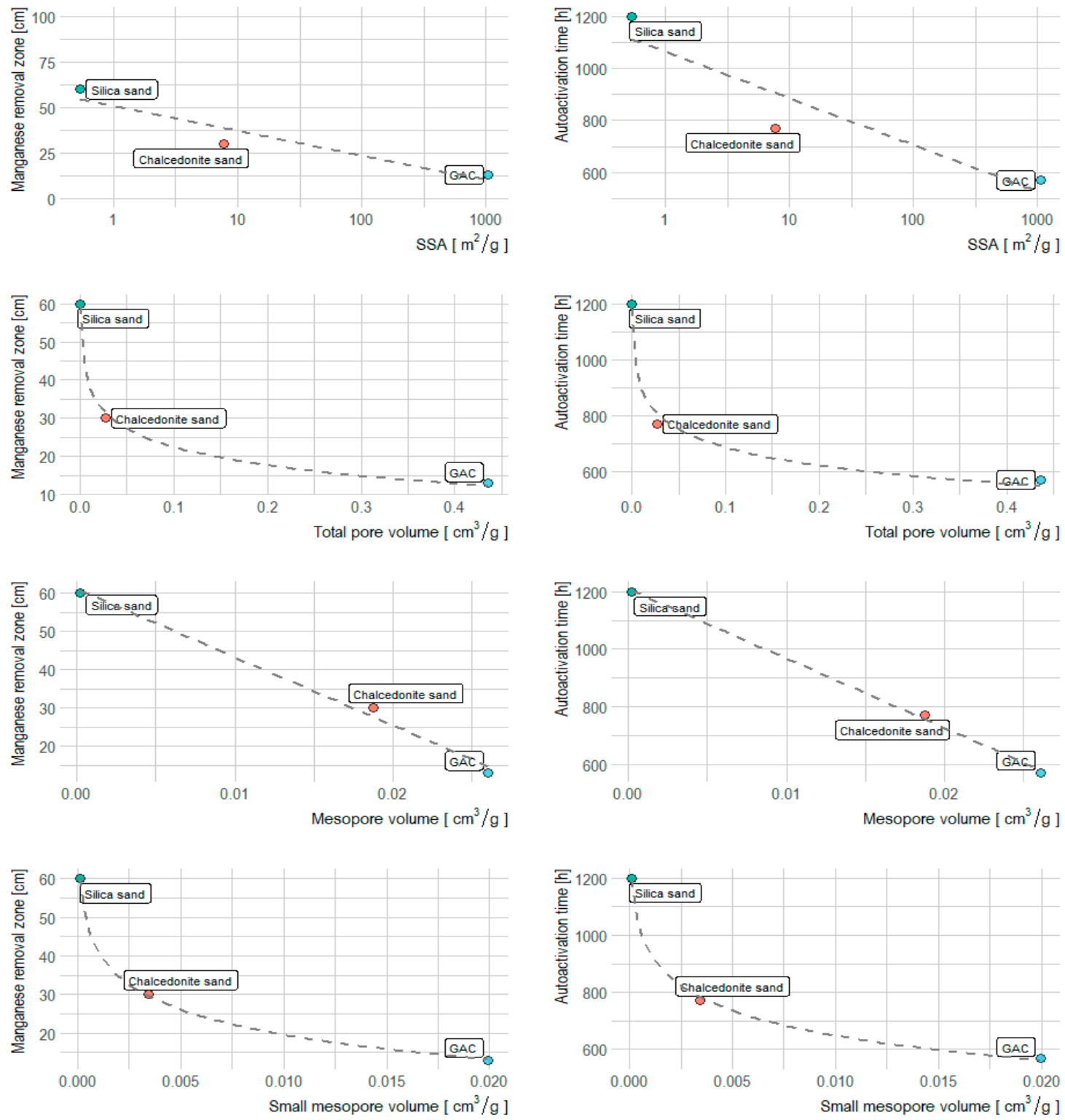

Figure 5. Impact of structure parameters of tested filtration materials on the height of manganese removal zone and auto-activation time.

The impact of structural parameters of the filtration materials on the auto-activation process was the subject of previous studies $[5,19]$. The results of this study show that both the auto-activation time and the magnitude of the removal zone decrease with increasing pore volume and SSA (Figure 5). Total pore volume and fine mesopore volume show a logarithmic trend with auto-activation parameters. For mesopores, this trend is linear, which may suggest that not all pore fractions are equally important for the auto-activation processes. The fraction of mesopores also controls SSA [21]. The auto-activation time and the magnitude of the Mn removal zone abruptly drop as SSA increases from $\sim 1$ to $\sim 10 \mathrm{~m}^{2} / \mathrm{g}$. However, a further increase of SSA (up to $\sim 1000 \mathrm{~m}^{2} / \mathrm{g}$ ) causes only a moderate improvement of the auto-activation parameters (Figure 5). This may suggest that the adsorption of $\mathrm{Mn}$ is not fully efficient in the micropore system characteristic for GAC.

For manganese removal, chalcedonite sand is characterized by short auto-activation time in comparison to silica sand. As reported in the literature, the auto-activation time of chalcedonite at the groundwater treatment plant was in the range of 27-48 days, and in comparison, the ripening period 
for silica sand was equal to 57 days [8]. According to the presented research, the time needed for auto-activation of chalcedonite sand for Mn removal does not depend on the filtration rate, although it affects the height of the manganese removal zone of the chalcedonite sand [8]. The two mechanisms of activation of filtration material, which result in the formation of active $\mathrm{MnO}_{2}$ centers on the grain surface, should be considered: Mn adsorption and Mn biological oxidation, as well as deposition of oxides on the surface of grains $[16,18]$. The internal pore structure is crucial for both mechanisms [32]. The adsorption of manganese on chemically non-active materials strongly depends on the porosity of the material subjected to activation [8]. It has been revealed that at the first stage of activation, the biological oxidation carried out by manganese bacteria is very important [16-18]. The presence of mesopores in chalcedonite sand (in contrast to non-porous silica sand) creates the condition for microbial growth and oxides deposition in pores [33].

Determining the relationship between the time of auto-activation and the internal pore structure parameters allows to pre-classify the filter materials used for manganese removal. The research results indicated that the method of initial classification can be based on the rapid measurement of pore structure parameters before making a decision regarding time-consuming pilot and technological tests. The research results indicated the purpose and scope of future studies on materials with different structures and different distributions of pores in order to enable the determination of the range of pore dimensions which affect the auto-activation process to the highest extent.

\section{Conclusions}

The research was devoted to the process of auto-activation of chemically inactive filtration materials for manganese removal. The auto-activation is time-consuming but results in the formation of a filter bed dedicated to a given type of water. The manganese removal in auto-activated materials is very effective and stable during prolonged periods. This stable and robust performance of auto-activated filtration material is an advantage compared to commercially available materials as their manganese removal efficiency depends on many parameters of raw water quality and the filtration process itself.

In this study, two auto-activation parameters were investigated: auto-activation time and the height of the manganese removal zone.

The experimental results revealed that GAC and chalcedonite sand are characterized by shorter auto-activation time than silica sand. The auto-activation times of tested filtration materials are as follows:

- GAC: $570 \mathrm{~h}$, approximately 24 days

- chalcedonite sand: 770 h, 32 days

- silica sand: $1200 \mathrm{~h}, 50$ days.

The time required for auto-activation correlates with internal pore structure parameters such as pore volume and SSA. The linear relation between mesopore volume and auto-activation time suggests that mesopores are mostly responsible for covering the grains with catalytic $\mathrm{MnO}_{2}$ oxide coating. On the other hand, the logarithmic trend between SSA and auto-activation time may imply that adsorption of $\mathrm{Mn}$ is not fully efficient in the micropore system. The role of different fractions of pores and SSA in the auto-activation process needs further investigation with the focus on samples with a well-developed mesopore system and various pore size distributions (e.g., zeolites).

The effects of manganese removal in the GAC bed increased gradually during auto-activation without fluctuations of efficiency even during the sudden and incidental increase of manganese concentration in raw water. GAC material was characterized by stable work, in contrast to chalcedonite and silica sand, which exhibited decreased performance when the manganese concentration suddenly increased in the inflow. The internal pore structure stabilizes the initial effects of manganese removal from treated water.

It can be assumed that the well-developed mesopore structure and associated SSA of chalcedonite and GAC grains significantly affect the adsorption potential capacity towards chemicals. 
The established manganese removal zone (top part of filtration bed removing the manganese to the level of $0.05 \mathrm{mg} / \mathrm{L}$ ) was the shortest in the GAC filter. The values of the established manganese removal zone are as follows:

- GAC: $13 \mathrm{~cm}$

- $\quad$ chalcedonite sand: $30 \mathrm{~cm}$

- $\quad$ silica sand: $60 \mathrm{~cm}$.

The silica sand needs the highest filtration bed for manganese removal. The final manganese removal zone is the shortest in the GAC bed. The determined manganese removal zone for tested materials strongly depends on internal structure parameters, as presented in Figure 5.

The established relations confirmed the impact of the internal pore structure of the material on auto-activation parameters. The higher the fractions of mesopores and SSA, the better the auto-activation parameters, such as auto-activation time and manganese removal zone depth.

Author Contributions: Conceptualization, J.J.-W.; methodology, J.J.-W. and T.T.; formal analysis, J.F., A.F., J.N. and L.D.; investigation, Z.D., J.F., A.F., J.J.-W., J.N., L.D. and T.T.; data curation, J.F., A.F., J.J.-W., J.N.; writing-original draft preparation, J.F., A.F., J.J.-W., J.N. and T.T.; writing-review and editing, Z.D., J.J.-W., L.D. and T.T.; visualization, T.T.; supervision, J.J.-W.; project administration, Z.D.; funding acquisition, Z.D. All authors have read and agreed to the published version of the manuscript.

Funding: This research was funded by Pozan University of Techology, grant number 01/13/SBAD/0913/2019.

Acknowledgments: The authors would like to thank Sylwia Kuińska-Ciążyńska and Mikołaj Gomoński for their technical support.

Conflicts of Interest: The authors declare no conflict of interest.

\section{References}

1. Jeż-Walkowiak, J.; Dymaczewski, Z.; Szuster-Janiaczyk, A.; Nowicka, A.B.; Szybowicz, M. Efficiency of Mn Removal of Different Filtration Materials for Groundwater Treatment Linking Chemical and Physical Properties. Water 2017, 9, 498. [CrossRef]

2. Bray, R.; Olańczuk-Neyman, K. The influence of changes in groundwater composition on the efficiency of manganese and ammonia nitrogen removal on mature quartz sand filtering beds. Water Sci. Technol. 2001, 1, 91-98. [CrossRef]

3. Jeż-Walkowiak, J.; Dymaczewski, Z. Effectiveness of oxidative filter materials for manganese removal from groundwater. J. Water Supply 2012, 61, 364-371. [CrossRef]

4. Postawa, A.; Jeż-Walkowiak, J.; Pruss, A.; Wator, K. Arsenic in Groundwaters near Lublin. Geol. Bull. Pol. Geol. Inst. 2011, 445, 495-504.

5. Michel, M.M. Characteristics of chalcedonite from Teofilów deposit for possible use in technology of water and wastewater treatment. Gospod. Surowcami Miner. Miner. Resour. Manag. 2011, 27, 49-67.

6. Bierlein, K.A.; Knocke, W.R.; Tobiason, J.E.; Subramaniam, A.; Pham, M.; Little, J.C. Modeling Manganese Removal in a Pilot-Scale Postfiltration Contactor. J. AWWA 2015, 107, E109-E119. [CrossRef]

7. Olańczuk-Neyman, K.; Bray, R. The Role of Physico-Chemical and Biological Processes in Manganese and Ammonia Nitrogen Removal from Groundwater. Pol. J. Environ. Stud. 2000, 9, 91-96.

8. Jeż-Walkowiak, J.; Dymaczewski, Z.; Weber, Ł. Iron and manganese removal from groundwater by filtration through a chalcedonite bed. J. Water Supply 2015, 64, 19-34. [CrossRef]

9. Vries, D.; Bertelkamp, C.; Schoonenberg Kegel, F.; Hofs, B.; Dusseldorp, J.; Bruins, J.H.; de Vet, W.; van den Akker, B. Iron and manganese removal: Recent advances in modelling treatment efficiency by rapid sand filtration. Water Res. 2017, 109, 35-45. [CrossRef]

10. Learman, D.R.; Voelker, B.M.; Vazquez-Rodriguez, A.I.; Hansel, C.M. Formation of manganese oxides by bacterially generated superoxide. Nat. Geosci. 2011, 4, 95-98. [CrossRef]

11. Breda, I.L.; Ramsay, L.; Roslev, P. Manganese oxidation and bacterial diversity on different filter media coatings during the start-up of drinking water biofilters. J. Water Supply 2017, 66, 641-650. [CrossRef]

12. Anovitz, L.M.; Cole, D.R. Characterization and Analysis of Porosity and Pore Structures. Rev. Mineral. Geochem. 2015, 80, 61-164. [CrossRef] 
13. Choma, J.; Zdenkowski, J.A. Surface and structural properties of mineral adsorbents. Environ. Prot. 2001, 4, 5-8.

14. Choma, J.; Jedynak, K.; Jamioła, D.; Jaroniec, M. Influence of carbonization temperature on the adsorption and structural properties of mesoporous carbons obtained by soft templating. Environ. Prot. 2012, 34, 3-8.

15. Sozański, M.; Huck, P.M. Badania Doświadczalne w Rozwoju Technologii Uzdatniania Wody (Experimental Research in Development of Water Treatment Technology); Komitet Inżynierii Środowiska PAN: Lublin, Poland, 2007; pp. 21-42.

16. Bruins, J.H.; Petrusevski, B.; Slokar, Y.M.; Huysman, K.; Joris, K.; Kruithof, J.C.; Kennedy, M.D. Factors controlling the ripening of manganese removal filters in conventional aeration-filtration groundwater treatment. Desalin. Water Treat. 2017, 72, 22-29. [CrossRef]

17. Bruins, J.H.; Petrusevski, B.; Slokar, Y.M.; Kruithof, J.C.; Kennedy, M.D. Manganese removal from groundwater: Characterization of filter media coating. Desalin. Water Treat. 2014, 1854-1863. [CrossRef]

18. Mouchet, P. From Conventional to Biological Removal of Iron and Manganese in France. J. AWWA 1992, 84, 158-167. [CrossRef]

19. Papciak, D.; Domoń, A.; Puszkarewicz, A.; Kaleta, J. The Use of Chalcedonite as a Biosorption Bed in the Treatment of Groundwater. Appl. Sci. 2019, 9, 751. [CrossRef]

20. Dudek, L. Novel method of pore space interpretation based on joint Mercury Intrusion Porosimetry and Nitrogen Adsorption of the selected Menilite Shales. Nafta-Gaz 2020, 5, 291-298. [CrossRef]

21. Rouquerol, J.; Llewellyn, P.; Rouquerol, F. Is the bet equation applicable to microporous adsorbents? Stud. Surf. Sci. Catal. 2007, 160, 49-56. [CrossRef]

22. Kuila, U.; Prasad, M. Specific surface area and pore-size distribution in clays and shales. Geophys. Prospect. 2013, 61, 341-362. [CrossRef]

23. Brown, A.A. Interpreting Permeability from Mercury Injection Capillary Pressure Data. In Proceedings of the AAPG Annual Convention and Exhibition, Denver, CO, USA, 31 May-3 June 2015; Volume 41660, pp. 3-5.

24. Comisky, J.T.; Newsham, K.; Rushing, J.A.; Blasingame, T.A. A Comparative Study of CapillaryPressure-Based Empirical Models for Estimating Absolute Permeability in Tight Gas Sands. In Proceedings of the SPE Annual Technical Conference and Exhibition, Anaheim, CA, USA, 11-14 November 2007. [CrossRef]

25. Lan, Y.; Davudov, D.; Moghanloo, R.G. Interplay between permeability and compressibility in shale samples. J. Pet. Sci. Eng. 2017, 159, 644-653. [CrossRef]

26. Washburn, E.W. Note on a Method of Determining the Distribution of Pore Sizes in a Porous Material. Proc. Natl. Acad. Sci. USA 1921, 7, 115-116. [CrossRef] [PubMed]

27. Rouquerol, J.; Rouquerol, F.; Sing, K.S.W. Absorption by Powders and Porous Solids, Methodology and Applications, 1st ed.; Academic Press: Cambridge MA, USA, 1998; ISBN 0080526012.

28. Groen, J.C.; Peffer, L.A.A.; Perez-Ramirez, J. Pore size determination in modified micro- and mesoporous materials. Pitfalls and limitations in gas adsorption data analysis. Micropor. Mesopor. Mater. 2003, 60. [CrossRef]

29. Mason, G. The effect of pore space connectivity on the hysteresis of capillary condensation in adsorption-desorption isotherms. J. Colloid Interface Sci. 1982, 88, 36-46. [CrossRef]

30. Mahajan, O.P.; Walker, P.L. Porosity of Coals and Coal Products. Analytical Methods for Coal and Coal Products, 1st ed.; Karr, J.R., Ed.; Academic Press Inc.: New York, NY, USA, 1978; pp. 125-162.

31. Michel, M.; Reczek, L.; Papciak, D.; Włodarczyk-Makuła, M.; Siwiec, T.; Trach, Y. Mineral Materials Coated with and Consisting of $\mathrm{MnOx}-$ Characteristics and Application of Filter Media for Groundwater Treatment: A Review. Materials 2020, 13, 2232. [CrossRef]

32. Sharma, S.K.; Greetham, M.R.; Schippers, J.C. Adsorption of iron(II) onto filter media. J. Water Supply 1999, 48, 84-91. [CrossRef]

33. Stenkamp, V.S.; Benjamin, M.M. Effect of iron oxide coatings on sand filtration. J. AWWA 1994, 86, 37-50. [CrossRef]

(C) 2020 by the authors. Licensee MDPI, Basel, Switzerland. This article is an open access article distributed under the terms and conditions of the Creative Commons Attribution (CC BY) license (http://creativecommons.org/licenses/by/4.0/). 